\title{
Potential use of Annona by products to control Drosophila suzukii and toxicity to its parasitoid Trichopria anastrephae
}

\author{
Daniel Bernardi ${ }^{\mathrm{a}}$, Leandro Ribeiro ${ }^{\mathrm{b}, *}$, Felipe Andreazza $^{\mathrm{c}}$, Camila Neitzke $^{\mathrm{a}}$, \\ Eugênio Eduardo Oliveira ${ }^{c}$, Marcos Botton ${ }^{\mathrm{d}}$, Dori Edson Nava ${ }^{\mathrm{a}}$, José Djair Vendramim ${ }^{\mathrm{e}}$

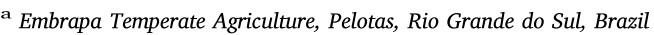 \\ ${ }^{\mathrm{b}}$ Research Center for Family Agriculture, Research and Rural Extension Company of Santa Catarina (EPAGRI/CEPAF), Chapecó, Santa Catarina, Brazil \\ c Department of Entomology, Federal University of Viçosa, Viçosa, Minas Gerais, Brazil \\ d Embrapa Grape and Wine, Bento Gonçalves, Rio Grande do Sul, Brazil \\ e Department of Entomology and Acarology, University of São Paulo, "Luiz de Queiroz" College of Agriculture (USP/ESALQ), Piracicaba, São Paulo, Brazil
}

\section{A R T I C L E I N F O}

\section{Keywords:}

Spotted wing Drosophila

Annona mucosa

Annonin

Rolliniastatin-1

Bioactivity

Sustainable pest management

\begin{abstract}
A B S T R A C T
Extracts of Annona (Annonaceae) plants have been shown to satisfactorily control several insect pest species, especially on Neotropical regions. Here, we tested the potential use of formulated ethanolic seed-extracts of three Annona species (i.e., A. mucosa Jacq., A. muricata L. and A. sylvatica A. St.-Hil) to control the invasive pest Drosophila suzukii Matsumura, 1931 (Diptera: Drosophilidae). Using a discriminatory concentration (i.e., $2000 \mathrm{mg} \mathrm{L}^{-1}$ ) for all the extracts, our results revealed that only the formulation based on $A$. mucosa seed-extract caused mortality above $85 \%$, which was equivalent to the mortality caused by the synthetic insecticide spinetoram, our positive control. However, $D$. suzukii laid significantly fewer eggs in strawberry fruits treated with any of the formulated Annona extracts when compared to fruits that were not subjected to insecticide applications. The concentration-mortality curves for A. mucosa formulated extracts on $D$. suzukii were determined, and the application of this extract at $\mathrm{LC}_{90}$ (i.e., $1,995.04 \mathrm{mg} \mathrm{L}^{-1}$ ) caused low mortality (33\%) of the parasitoid Trichopria anastrephae Lima (Hymenoptera: Diapriidae) though ingestion exposure; however, it was toxic (70\% mortality) to this natural enemy of $D$. suzukii by means of contact exposition. Behavior of parasitoids that survived exposure to the $\mathrm{LC}_{90}$ of $A$. mucosa formulated extract or of spinetoram (i.e., $105.34 \mathrm{mg} \mathrm{L}^{-1}$ ) was not significantly affected. Thus, the $A$. mucosa formulated extract exhibited potential to be used in the management programs of $D$. suzukii, especially in organically based production systems where there are fewer control tools available.
\end{abstract}

\section{Introduction}

Among the many plant families occurring in the Neotropical region, the Annonaceae is considered one of the best sources of compounds with insecticidal properties, especially due to the high diversity of secondary compounds (allelochemicals) that are synthesized and accumulated in different plant parts (Ribeiro et al., 2016). Phytochemical studies have identified a wide array of bioactive compounds in species of Annonaceae plants, particularly acetogenins (ACG), which have diverse chemical structures and potent insecticidal/acaricidal properties (Blessing et al., 2010). The acetogenins comprise a series of natural products (C-35/C-37) derived from long-chain fatty acids (C-32/C-34) combined with a unit of 2-propanol (Alali et al., 1999). These molecules have been found in high concentration in the seeds of some plant genera [Annona, Anomianthus, Asimina, Desepalum, Goniothalamus, Rollinia (now Annona), Polyalthia, Porcelia, Uvaria, and Xylopia] of the
Annonaceae family (Johnson et al., 2000).

Acetogenins are potent mitochondrial poisons, inhibiting cellular energy production (Isman and Seffrin, 2014). More specifically, acetogenins block the respiratory chain at complex I (NADH:ubiquinone oxidoreductase) of the mitochondrial electron transport system and the enzyme NADH:oxidase in the cell membrane of target arthropods, directly affecting electron transport in the mitochondria and causing apoptosis as result of ATP deprivation (Alali et al., 1999). Moreover, in a recent study, acetogenins at sub-lethal doses caused damage in the insect midgut epithelium and digestive cells, decreasing the expression of genes associated with transport and absorption of nutrients, metabolites and nonelectrolytes and increasing the expression of genes linked with autophagy induction (Costa et al., 2016). In addition to lethal toxicity (Ansante et al., 2015; Gonçalves et al., 2015; Ribeiro et al., 2013, 2014a,b,c,d, 2015, 2016; Souza et al., 2017), acetogeninbased extracts or isolated compounds also affect development, feeding

\footnotetext{
* Corresponding author at: EPAGRI/CEPAF, Rua Ferdinando Ricieri Tusset S/N, Bairro São Cristóvão, Caixa Postal 791, CEP: 89801-970, Chapecó, Santa Catarina, Brazil.

E-mail addresses: leandro_universidade@hotmail.com, leandroribeiro@epagri.sc.gov.br, lpribeiro@usp.br (L. Ribeiro).
} 
and oviposition behavior in insects (Ansante et al., 2015; Ribeiro et al., 2015; Gonçalves et al., 2017; Souza et al., 2017). However, to date, we are unaware of any published studies that describe the bioactivity of annonaceous derivatives or isolated acetogenins in the realm of Drosophila suzukii Matsumura, 1931 (Diptera: Drosophilidae), an invasive pest that has caused severe losses in small berry or soft fruit fields in all producing countries (Cini et al., 2012; Asplen et al., 2015).

Native to Asia, D. suzukii dispersed rapidly throughout North America, Europe and South America (Cini et al., 2012; Santos, 2014; Schlesener et al., 2014; Asplen et al., 2015; Andreazza et al., 2016b). This species is recognized as a serious phytosanitary threat in many countries (Hamby et al., 2016) because of the many factors related to its biology, such as its wide host range (Lee et al., 2015; Poyet et al., 2015), dispersion capability (Haye et al., 2016) and its short generation time (Tochen et al., 2014; Asplen et al., 2015). As an emergency control strategy, the application of synthetic organophosphorous, pyrethroid and spinosyn insecticides are the most used approach to manage $D$. suzukii worldwide (Bruck et al., 2011; Haviland and Beers, 2012; Van Timmeren and Isaacs, 2013; Haye et al., 2016).

Although effective, the continuous use of synthetic insecticides results in environmental contamination, toxicological risks, selection for insecticide-resistant populations and adverse effects on beneficial fauna (Roubos et al., 2014). Additionally, many berry fields in large production countries, such as Brazil, are small properties cultivated under organic or low residue policies in which the use of synthetic substances are banned or restricted (Zanardi et al., 2015). Thus, the development of new management alternatives that meet the standards of organic production or the low residue policies of the international trade market has become sorely needed. In this context, botanical insecticides might have an important role in integrated pest management (IPM) programs for $D$. suzukii, particularly as alternatives to the synthetic insecticides (Isman and Grieneisen, 2014).

Thus, the aim of the present investigation was to assess the toxicity of formulated ethanolic extracts obtained from the seeds of Annona species (e.g., A. mucosa Jacq., A. muricata L. and A. sylvatica A. St.-Hil) on $D$. suzukii adults. A spinosyn-based (i.e., spinetoram) and an acetogenin-based (i.e., annonin) commercial insecticide were used as positive controls. Furthermore, we evaluated residues of these products on the oviposition behavior of $D$. suzukii and whether the most promising extracts were selective against the $D$. suzukii parasitoid, Trichopria anastrephae Lima (Hymenoptera: Diapriidae). This parasitoid was recently found parasitizing D. suzukii pupae in Brazil (Wollmann et al., 2016; Andreazza et al., 2017b).

\section{Materials and methods}

\subsection{Formulated extracts: sources and preparation}

Information on the origin of Annona species used in this study (Table 1) is detailed in Ribeiro et al. (2014c, 2016). Voucher specimens of these species, previously identified by Prof. Dr. Renato Mello-Silva [Department of Botany, Biosciences Institute/University of São Paulo (IB/USP)], are deposited in the herbarium of the Department of Biological Sciences at "Luiz de Queiroz" College of Agriculture/University of São Paulo, Piracicaba Municipality, São Paulo State, Brazil.

To prepare the extracts, seeds collected from ripe fruits were ovendried at $38{ }^{\circ} \mathrm{C}$ for $48 \mathrm{~h}$. Seeds were then milled to a powder in a knife mill. Powders were stored in sealed glass containers and stored at approximately $-10{ }^{\circ} \mathrm{C}$ until use. Organic extracts were obtained by cold maceration using ethanol as a solvent $(5: 1, \mathrm{v}: \mathrm{w})$, with the seed powder held in ethanol for three days, followed by filtering through filter paper. The filtrate was immersed in solvent again, being this process repeated three times. Remaining solvent was removed in vacuo at $50{ }^{\circ} \mathrm{C}$. After complete evaporation of the solvent in an airflow chamber, the extraction yield for each species was determined. For preparation of the formulations that would produce aqueous emulsions when diluted with water, the extracts were solubilized in acetone:methanol $(1: 1, \mathrm{v}: \mathrm{v})$ $\left(100 \mathrm{~g} \mathrm{~L}^{-1}\right)$, with the subsequent addition of Tween ${ }^{\circ} 80$ emulsifier at a concentration of $10 \mathrm{~g} \mathrm{~L}^{-1}$. All the dilutions were done to a final volume of $100 \mathrm{~mL}$ of each desired concentrations (Table 1).

\subsection{Test insects}

The $D$. suzukii (20th generation) and $T$. anastrephae (10th generation) individuals used in all bioassays were obtained from laboratory stock colonies maintained at $25 \pm 2{ }^{\circ} \mathrm{C}, 70 \pm 5 \%$ relative humidity and a $12 \mathrm{~h}$ photophase. The flies were reared and fed on artificial diet following the methodology described by Andreazza et al. (2016a). The T. anastrephae parasitoids were reared on D. suzukii pupae and fed honey/water ( $80 \%$, w:v). Before each bioassay, four-day-old adults of both species were deprived of food for $8 \mathrm{~h}$, but with water provided.

\subsection{Bioassays}

All bioassays were performed under laboratory conditions at $25 \pm 2{ }^{\circ} \mathrm{C}, 70 \pm 10 \%$ relative humidity and a $12 \mathrm{~h}$ photophase, using a completely randomized design. The formulated synthetic insecticide Delegate $250 \mathrm{WG}^{\mathrm{m}}$, which contained the active ingredient spinetoram, was used at the field rate $\left(75 \mathrm{mg}\right.$ of a.i. $\left.\mathrm{L}^{-1}\right)$ as a positive control (Table 1). In addition to the laboratory extracts of the three selected Annona species (described in 2.1 and Table 1), a commercial bioinsecticide containing acetogenins was tested [Anosom ${ }^{\circ}$ (AgriLife SOM

Table 1

Insecticides evaluated for the management of Drosophila suzukii.

\begin{tabular}{|c|c|c|c|}
\hline Treatments & Description & $\begin{array}{l}\text { Discriminatory concentration } \\
\text { tested }^{\mathrm{a}}\end{array}$ & Origin/manufacturer \\
\hline Anosom $1 \mathrm{EC}$ & $\begin{array}{l}\text { Annona squamosa } \mathrm{L} \text {. and Annona reticulata } \mathrm{L} \text {. extracts based } \\
\text { bioinsecticide [acetogenin annonin }\left(10.000 \mathrm{mg} \mathrm{L}^{-1}\right) \text { ] }\end{array}$ & 2000 & $\begin{array}{l}\text { Agrilife Biosolutions, Ltda. (Hyderabad, } \\
\text { Andhra Pradesh, India) }\end{array}$ \\
\hline ESE Annona mucosa & $\begin{array}{l}\text { Aqueous emulsion of ethanolic seed-extract of Annona mucosa Jacq. } \\
\text { (pre-commercial) }\end{array}$ & 2000 & Laboratory extraction and formulation \\
\hline ESE Annona muricata & $\begin{array}{l}\text { Aqueous emulsion of ethanolic seed-extract of Annona muricata L. (pre- } \\
\text { commercial) }\end{array}$ & 2000 & Laboratory extraction and formulation \\
\hline ESE Annona sylvatica & $\begin{array}{l}\text { Aqueous emulsion of ethanolic seed-extract of Annona sylvatica A. St.- } \\
\text { Hil. (pre-commercial) }\end{array}$ & 2000 & Laboratory extraction and formulation \\
\hline Delegate $250 \mathrm{WG}^{\mathrm{TM}}$ & Spinetoram $\left(250 \mathrm{~g} \mathrm{Kg}^{-1}\right)$ & $300^{\mathrm{b}}$ & $\begin{array}{l}\text { Dow AgroSciences Industrial Ltda., São } \\
\text { Paulo, SP, Brazil }\end{array}$ \\
\hline
\end{tabular}

*The concentration of $4000 \mathrm{mg} \mathrm{L}^{-1}$ of each extract was used for the oviposition deterrence test; ESE = Formulated ethanolic seed extract.

a Concentration: $\mathrm{mg}$ of extract or commercial product per $\mathrm{L}$ of water.

${ }^{b} 75 \mathrm{mg}$ of a.i. per L of water. 
Phytopharma Ltda., Hyderabad, Andhra Pradesh State, India]. This formulation is prepared from seed-extracts of Annona squamosa L. and Annona reticulata $\mathrm{L}$. and has the acetogenin annonin $\left(10,000 \mathrm{mg} \mathrm{L}^{-1}\right)$ as the primary active ingredient.

\subsubsection{Annona toxicities and lethal concentrations of the active treatments on D. suzukii}

To test the toxicity of the selected extracts, initial tests were performed using discriminatory concentrations on $D$. suzukii adults (Table 1). For these initial tests and further lethal concentrations bioassays, the product's toxicities on $D$. suzukii adults were assessed using both ingestion and contact exposure procedures.

For the ingestion bioassays, insects were separated into groups (sample units) of 20 adults per cage. Each cage was made of a clear plastic cup (1 L) flipped upside down on a plastic Petri dish $(25 \mathrm{~cm}$ in diameter) with its top (cup bottom) sealed with a voile mesh for ventilation. After appropriate dilutions in water, the products were offered to the insects via capillarity in a saturated cotton rolls, held inside a $10 \mathrm{~mL}$ glass vial for $24 \mathrm{~h}$. After this period, $10 \mathrm{~mL}$ glass vial containing the treated cotton roll was replaced by food and distilled water until the end of the evaluation period.

For the ingestion bioassays, insects were separated into groups (sample units) of 20 adults per cage. The cages consisted of transparent plastic containers $(1 \mathrm{~L})$ flipped upside down on a plastic Petri dish ( $25 \mathrm{~cm}$ in diameter). The cagés upper side (i.e, container bottom) was sealed with a voile mesh (i.e., organza) allowing ventilation inside the cages. During the exposure time (i.e., $24 \mathrm{~h}$ ), the flies could feed in cotton rolls (product traits) saturated with product-containing solutions placed inside a $10 \mathrm{~mL}$ glass vial that were held inside the cages. After the exposure period, the $10 \mathrm{~mL}$ glass vial containing the treated cotton roll was replaced by food and distilled water until the end of the evaluation period.

In these initial tests, it was used 4 replicates of 20 flies per treatment (products) $(n=80)$ in the ingestion bioassay and, 10 replicates of 10 insects per treatment (products) $(n=100)$ in the contact bioassay. Mortality was evaluated at $120 \mathrm{~h}$ after initial exposure to the treatment. A fly was considered dead when no movement occurred even after the touch of a fine brush.

Based on the results from this initial test, the most promising treatment (formulated ethanolic seed-extract from A. mucosa) and the positive control (spinetoram) were further evaluated to estimate the concentration required to kill $50 \%$ and $90 \%$ of exposed flies [Lethal concentration (LC), $\mathrm{LC}_{50}$ and $\mathrm{LC}_{90}$, respectively]. Therefore, seven concentrations (range: $125-4000 \mathrm{mg} \mathrm{L}^{-1}$ for the A. mucosa formulated extract and $10-100 \mathrm{mg} \mathrm{L}^{-1}$ for spinetoram) were tested for each product and mode of exposure based on the Finney (1971) procedure. The exposure and evaluation procedures and criteria were identical to those of the initial tests. In the ingestion bioassays, four replicates of 20 flies $(n=80)$ for each concentration of each product $(n=560)$ were used, whereas in the contact bioassays, 10 replicates of 10 flies $(n=100)$ for each concentration of each product $(n=700)$ were used.

2.3.2. Effects of formulated Annona seed-extracts on D. suzukii oviposition

Ripe and undamaged 'Aromas' strawberries without previous insecticide exposure were dipped in the treatment solutions (Table 1) for $5 \mathrm{~s}$ and then dried on filter paper for three hours. Later, each fruit (sample unit) was placed inside a cage containing two four-day-old pairs of $D$. suzukii flies for oviposition. The cages were clear plastic cups (200 $\mathrm{mL}$ ) flipped upside down on a Petri dish $(8 \mathrm{~cm}$ in diameter). After $24 \mathrm{~h}$, the adults were removed, and the eggs in the fruit (internal or external epidermis) were counted with the aid of a stereoscopic microscope (40x). Fifty replicates were examined per treatment.

\subsubsection{Toxicities and sub-lethal effects of the active treatments on $T$. anastrephae}

To evaluate the selectivity of the active treatments on the $D$. suzukii parasitoid T. anastrephae, the values for the $\mathrm{LC}_{90}$ of the formulated $A$. mucosa seed-extract and spinetoram were used in each exposure procedure, which were determined previously ( $120 \mathrm{~h}$ of exposure time). Adult wasps were submitted to both exposure procedures described in 2.3.1. Wasp mortality was evaluated at $120 \mathrm{~h}$ following the beginning of exposure using the same criteria to evaluate death as in $D$. suzukii.

To evaluate the sub-lethal effects of the treatments on the wasps, ten pupae of $D$. suzukii (24-h-old pupae) were offered, per day, for seven days (beginning at $120 \mathrm{~h}$ ), to each surviving $T$. anastrephae female from the ingestion bioassay. The pupae, obtained from the laboratory colony (as described in 2.2), were exposed to the wasps on a wet hydrophilic cotton layer on an acrylic Petri dish. Pupae were removed daily, and placed in plastic cups $(100 \mathrm{~mL})$ sealed on top with voile until the fly or wasp emergence. During the evaluation period, the wasps were fed $80 \%$ honey/water (w/v). Percentage parasitism was determined by dividing the total number of wasp offspring per total number of pupae offered, multiplied by 100 .

\subsection{Data analyses}

Generalized linear models of the exponential family of distributions (Nelder and Wedderburn, 1972) were used for the analyses of studied variables. The verification of quality adjustment was performed through the half-regular graph odds with simulation envelope (Hinde and Demétrio, 1998). When significant differences were detected among treatments, multiple comparisons (Tukey's test, $P<0.05$ ) were performed using the glht function in the Multicomp package, with adjustment of $p$-values. All analyses were performed using the " $R$ " statistical software version 2.15.1 (R Development Core Team, 2012).

A binomial model with a complementary log-log link function (gompit model) was used to estimate the lethal concentrations $\left(\mathrm{LC}_{50}\right.$ and $\mathrm{LC}_{90}$ ) using the Probit Procedure in the SAS statistical software package version 9.2 (SAS Institute, 2011).

\section{Results}

At $120 \mathrm{~h}$ after exposure, the formulation based on ethanolic extract of A. mucosa seeds $\left(2000 \mathrm{mg} \mathrm{L}^{-1}\right)$ showed toxicity similar $\left(\mathrm{F}_{5,12}=75.32, P<0.0001\right)$ to that with spinetoram $\left(75 \mathrm{mg} \mathrm{L}^{-1}\right)$, with approximately $90 \%$ fly mortality via ingestion (Fig. 1). These values were significantly higher than those of the commercial acetogeninbased bioinsecticide and the formulated seed-extracts from $A$. sylvatica

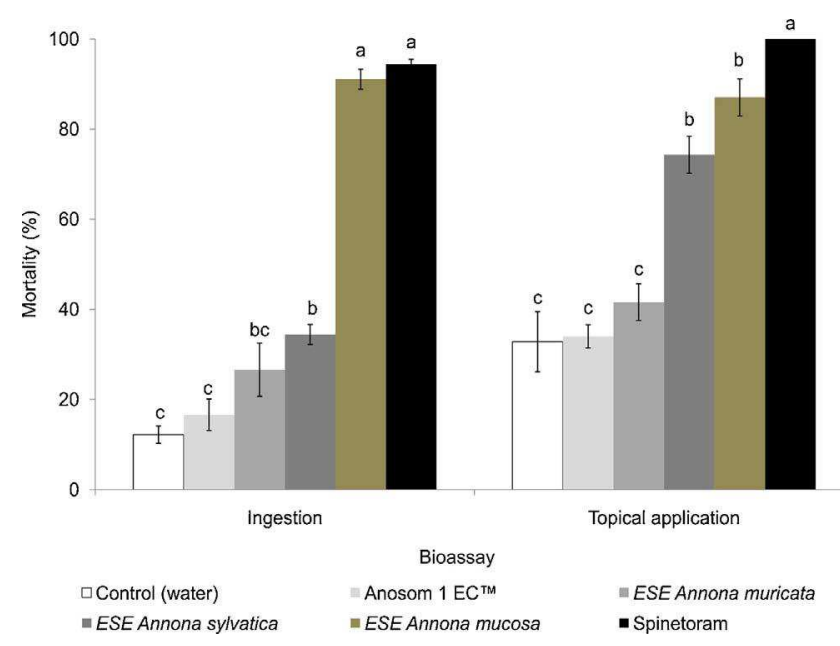

Fig. 1. Mortality (\%) ( \pm SE) of Drosophila suzukii at $120 \mathrm{~h}$ after exposure to treatments in laboratory bioassays. Means followed by different letters on the columns (within each exposition bioassay) indicate significant differences between treatments (GLM with quasibinomial distribution followed by post hoc Tukey test, $P<0.05$ ); ESE $=$ Formulated ethanolic seed extract. 
Table 2

Insecticidal activity of Annona mucosa (Annonaceae) formulated seed extract and spinosyn-based insecticide on $D$. suzukii adults in ingestion bioassay

\begin{tabular}{|c|c|c|c|c|c|c|c|}
\hline Exposure time (hours) & Treatments & $n$ & Slope \pm SE & $\mathrm{LC}_{50}(\mathrm{CI} 95 \%)^{\mathrm{a}}$ & $\mathrm{LC}_{90}(\mathrm{CI} 95 \%)^{\mathrm{b}}$ & $\chi^{2 c}$ & d.f. ${ }^{d}$ \\
\hline \multirow[t]{2}{*}{12} & ESE Annona mucosa & 80 & $2.79 \pm 0.60$ & $1,666.13(1,010.11-2,400.08)$ & $4,785.12(3,068.11-11,984.10)$ & 10.15 & 4 \\
\hline & Spinetoram & 80 & $3.99 \pm 1.25$ & $67.51(25.55-86.00)$ & $141.25(103.96-487.11)$ & 15.27 & 5 \\
\hline \multirow[t]{2}{*}{24} & ESE Annona mucosa & 80 & $3.32 \pm 1.04$ & $984.88(726.13-1,816.10)$ & $3,394.10(1,134.16-7,136.13)$ & 7.86 & 4 \\
\hline & Spinetoram & 80 & $2.43 \pm 0.29$ & $39.89(32.40-46.79)$ & $134.02(109.48-179.81)$ & 8.39 & 5 \\
\hline \multirow[t]{2}{*}{48} & ESE Annona mucosa & 80 & $1.60 \pm 0.34$ & $584.11(220.93-1,305.11)$ & $2,691.00(1,538.07-5,195.70)$ & 9.17 & 4 \\
\hline & Spinetoram & 80 & $1.85 \pm 0.48$ & $29.09(5.09-50.81)$ & $133.19(75.55-308.11)$ & 12.26 & 4 \\
\hline \multirow[t]{2}{*}{72} & ESE Annona mucosa & 80 & $1.83 \pm 0.49$ & $569.75(411.56-1,195.79)$ & $2,837.05(1,239.08-5,674.10)$ & 12.15 & 4 \\
\hline & Spinetoram & 80 & $1.39 \pm 0.21$ & $22.00(15.88-29.42)$ & $132.51(109.64-439.83)$ & 1.54 & 4 \\
\hline \multirow[t]{2}{*}{96} & ESE Annona mucosa & 80 & $2.13 \pm 0.71$ & $571.46(410.56-1231.18)$ & $2,214.19(1,611.14-4,684.90)$ & 10.80 & 4 \\
\hline & Spinetoram & 80 & $1.50 \pm 0.21$ & $18.03(13.00-23.59)$ & $127.75(83.33-258.01)$ & 5.55 & 4 \\
\hline \multirow[t]{2}{*}{120} & ESE Annona mucosa & 80 & $2.13 \pm 0.54$ & 500.43 (367.06-914.89) & $1,995.04(1,067.03-4,452.3)$ & 8.38 & 4 \\
\hline & Spinetoram & 80 & $1.51 \pm 0.37$ & $15.08(1.61-34.29)$ & $105.34(42.79-355.14)$ & 9.47 & 4 \\
\hline
\end{tabular}

${ }^{a} \mathrm{LC}_{50}$ and $\mathrm{LC}_{90}$ : Concentrations (mg L ${ }^{-1}$ ) required to kill 50 or $90 \%$ of the adults of $D$. suzukii, respectively, CI: confidence interval at $95 \%$.

${ }^{\mathrm{b}} \mathrm{LC}_{50}$ and $\mathrm{LC}_{90}$ : Concentrations ( $\mathrm{mg} \mathrm{L}^{-1}$ ) required to kill 50 or $90 \%$ of the adults of $D$. suzukii, respectively, CI: confidence interval at $95 \%$ "a" and "b" have the same sentence. I suggest to include the same letter ("a") in the table and remove the second sentence.

' $\chi^{2}$ : Pearson's chi-square value.

d df: degrees of freedom; ESE $=$ Formulated ethanolic seed extract

and A. muricata ( $<35 \%$; Fig. 1). By contrast, using the contact bioassay on D. suzukii, the formulated extracts from both A. mucosa and A. sylvatica caused higher mortality $(>74 \%)\left(\mathrm{F}_{5,12}=54.66, P<0.0001\right)$ than the commercial acetogenin-based bioinsecticide and the formulated extract from A. muricata $(<42 \%$; Fig. 1). However, both of formulated extracts were less toxic than the spinetoram insecticide (100\% mortality; Fig. 1)

Based on the probit analysis from the ingestion bioassay, the toxicity of a formulated A. mucosa seed-extract was dependent on the evaluation time, with the $\mathrm{LC}_{50}$ differing significantly between 12 and $120 \mathrm{~h}$ (Table 2). For the contact bioassays, the $\mathrm{LC}_{50}$ at $120 \mathrm{~h}$ significantly differed from both the $\mathrm{LC}_{50}$ at 12 and $24 \mathrm{~h}$ (Table 3). The pattern was similar for the insecticide spinetoram in the ingestion bioassay (Table 2). However, in the contact bioassay the $\mathrm{LC}_{50}$ values for spinetoram decreased significantly only among the first $48 \mathrm{~h}$ (Table 3 ).

The dried residues of all the products (Annona formulated extracts, acetogenin-based bioinsecticide and spinetoram) deterred oviposition of $D$. suzukii on the strawberry fruits (from 12.86 to 17.06 eggs per fruit) compared with the control (23.14 eggs per fruit; $\mathrm{F}_{5,29}=27.55$, $P<0.0001$; Fig. 2). An approximate $45 \%$ reduction in oviposition was recorded in fruits previously treated with formulation based on $A$. mucosa extract, whereas the reduction was only approximate $26 \%$ when

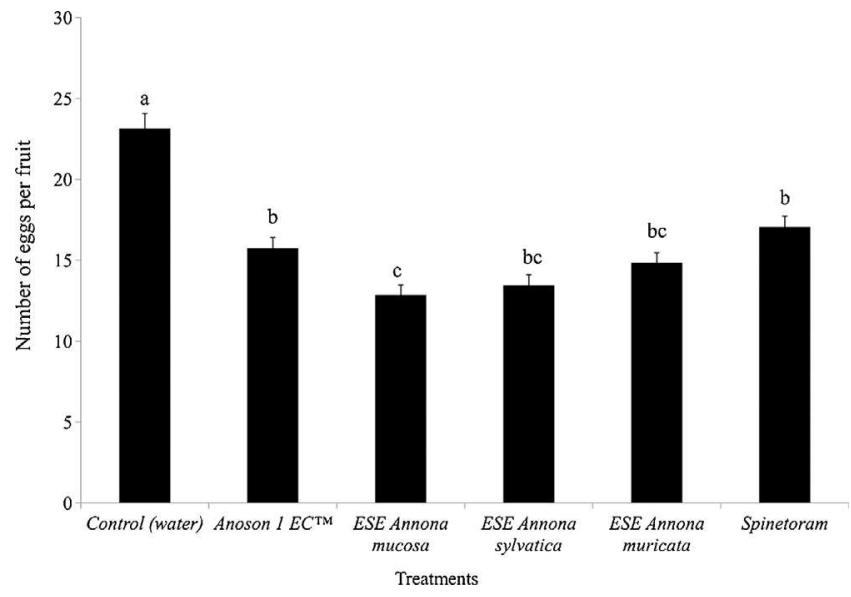

Fig. 2. Effect of a formulated ethanolic seed-extract from Annona species and the spinosyn-based synthetic insecticide on the oviposition of Drosophila suzukii females in strawberry fruits. Bars ( \pm SE) with the same letter are not significantly different (GLM with a quasi-binomial distribution followed by Tukey post hoc test: $P<0.05$ ). ESE $=$ Formulated ethanolic seed extract.

Table 3

Insecticidal activity of $A$. mucosa (Annonaceae) formulated seed extract and spinosyn-based insecticide on $D$. suzukii adults in contact bioassay.

\begin{tabular}{|c|c|c|c|c|c|c|c|}
\hline Exposure time (hours) & Treatments & $n$ & Slope \pm SE & $\mathrm{LC}_{50}(\mathrm{CI} 95 \%)^{\mathrm{a}}$ & $\mathrm{LC}_{90}(\mathrm{CI} 95 \%)^{\mathrm{b}}$ & $\chi^{2 c}$ & d.f. ${ }^{\text {d }}$ \\
\hline \multirow[t]{2}{*}{12} & ESE Annona mucosa & 761 & $1.51 \pm 0.16$ & $2,623.02(2,160.02-3,169.01)$ & - & 4.02 & 5 \\
\hline & Spinetoram & 1181 & $2.42 \pm 0.33$ & $69.19(58.07-83.05)$ & $233.16(166.24-436.74)$ & 14.52 & 8 \\
\hline \multirow[t]{2}{*}{24} & ESE Annona mucosa & 761 & $1.56 \pm 0.16$ & $1,826.01(1,485.00-2,192.08)$ & - & 6.17 & 5 \\
\hline & Spinetoram & 1181 & $2.96 \pm 0.25$ & $41.10(36.52-45.32)$ & $111.33(98.51-130.42)$ & 10.61 & 8 \\
\hline \multirow[t]{2}{*}{48} & ESE Annona mucosa & 761 & $1.52 \pm 0.21$ & $1,176.03(796.80-1,521.03)$ & $8,129.00(6,008.03-13,144.10)$ & 8.06 & 5 \\
\hline & Spinetoram & 1181 & $3.81 \pm 0.32$ & $29.41(25.79-32.61)$ & $63.80(58.54-70.65)$ & 10.12 & 8 \\
\hline \multirow[t]{2}{*}{72} & ESE Annona mucosa & 761 & $1.86 \pm 0.50$ & $1,336.11(891.61-2,199.25)$ & $6,483.19(3,961.73-10,935.24)$ & 12.51 & 5 \\
\hline & Spinetoram & 1181 & $4.03 \pm 0.42$ & $26.28(22.05-29.81)$ & $54.57(49.84-60.67)$ & 10.75 & 8 \\
\hline \multirow[t]{2}{*}{96} & ESE Annona mucosa & 761 & $1.81 \pm 0.61$ & $1,083.27(926.09-1,977.13)$ & $5,512.36(3,365.17-6,648.25)$ & 11.93 & 5 \\
\hline & Spinetoram & 971 & $3.94 \pm 0.52$ & $25.03(20.04-28.91)$ & $52.92(47.40-61.13)$ & 7.52 & 6 \\
\hline \multirow[t]{2}{*}{120} & ESE Annona mucosa & 761 & $1.15 \pm 0.27$ & $440.71(270.47-1,045.13)$ & $5,013.12(2,763.84-6,398.25)$ & 12.29 & 5 \\
\hline & Spinetoram & 971 & $4.06 \pm 1.14$ & $25.96(17.27-34.74)$ & $53.62(42.29-94.73)$ & 14.59 & 6 \\
\hline
\end{tabular}

${ }^{\mathrm{a}} \mathrm{LC}_{50}$ and $\mathrm{LC}_{90}$ : Concentrations (mg L ${ }^{-1}$ ) required to kill 50 or $90 \%$ of the adults of $D$. suzukii, respectively, CI: confidence interval at $95 \%$.

${ }^{\mathrm{b}} \mathrm{LC}_{50}$ and $\mathrm{LC}_{90}$ : Concentrations ( $\mathrm{mg} \mathrm{L}^{-1}$ ) required to kill 50 or $90 \%$ of the adults of $D$. suzukii, respectively, CI: confidence interval at $95 \%$. Idem Table 2 .

' $\chi^{2}$ : Pearson's chi-square value.

df: degrees of freedom; ESE $=$ Formulated ethanolic seed extract. 
Table 4

Mortality and parasitism ( \pm SE) of Trichopria anastrephae at $120 \mathrm{~h}$ after exposure to selected treatments in a laboratory ingestion and contact bioassays.

\begin{tabular}{|c|c|c|c|c|}
\hline \multirow[t]{2}{*}{ Treatments } & \multirow[t]{2}{*}{ Concentration $\left(\mathrm{mg} \mathrm{L}^{-1}\right)^{\mathrm{a}}$} & \multicolumn{2}{|l|}{ Mortality $(\%)^{\mathrm{b}}$} & \multirow[t]{2}{*}{ Parasitism $(\%)^{\mathrm{b}}$} \\
\hline & & Ingestion bioassay & Contact bioassay & \\
\hline ESE Annona mucosa & 1995.04 & $31.5 \pm 1.50 \mathrm{~b}$ & $70.9 \pm 5.94 a$ & $55.5 \pm 2.21 \mathrm{a}$ \\
\hline Spinetoram & 105.34 & $60.0 \pm 4.26 \mathrm{a}$ & $64.9 \pm 6.96 a$ & $51.9 \pm 5.51 \mathrm{a}$ \\
\hline Control (Water) & - & $6.5 \pm 2.18 c$ & $23.1 \pm 4.70 \mathrm{~b}$ & $55.5 \pm 0.43 a$ \\
\hline
\end{tabular}

${ }^{a}$ Concentration estimated based on $\mathrm{LC}_{90}$ values in ingestion bioassay on Drosophila suzukii.

${ }^{\mathrm{b}}$ Means within a column followed by the same letter do not differ significantly (GLM with a quasi-binomial distribution followed by Tukey post hoc test: $P<0.05$ ). ESE $=$ Formulated ethanolic seed extract.

previously treated with the spinetoram insecticide $\left(\mathrm{F}_{5,29}=27.55\right.$, $P<0.0001$; Fig. 2).

The contact exposure at the $\mathrm{LC}_{90}$ of both the formulated $A$. mucosa seed-extract and spinetoram resulted in similar mortality of the parasitoid $T$. anastrephae, with the mortality of both higher than that of the negative control (water) $\left(\mathrm{F}_{2,12}=17.02, P<0.0003\right.$; Table 4). However, in the ingestion bioassay, the mortality caused by the formulated A. mucosa seed-extract was significantly lower than that of the spinetoram insecticide $\left(\mathrm{F}_{2,12}=65.59, P<0.0001\right)$, although still higher than that of the control (Table 4). Finally, the parasitism rate of $D$. suzukii pupae by T. anastrephae was not significantly affected by either treatment $\left(\mathrm{F}_{2,11}=0.65, P<0.5403\right)$ compared with the control (Table 4).

\section{Discussion}

In the present study, the toxicities of selected Annonaceae seed extracts on $D$. suzukii and its parasitoid $T$. anastrephae were assessed. The bioactivity of the formulated A. mucosa extract was equivalent to that of a commercial insecticide containing spinetoram, and for the first time, the action of Annonaceae derivatives against D. suzukii was demonstrated. Several studies demonstrate the toxicity of $A$. mucosa extracts to other pest species, including Sitophilus zeamais Motschulsky (Coleoptera: Curculionidae) (Ribeiro et al., 2013), Panonychus citri (McGregor) (Prostigmata: Tetranychidae) (Ribeiro et al., 2014b), Trichoplusia ni Hübner (Lepidoptera: Noctuidae) and Myzus persicae (Sulzer) (Aphidomorpha: Aphididae) (Ribeiro et al., 2014c), Spodoptera frugiperda (J.E. Smith) (Lepidoptera: Noctuidae) (Ansante et al., 2015) and Helicoverpa armigera (Souza et al., 2017). Subsequently, bio-monitored fractionations indicated that the acute and chronic toxicity of this botanical derivative is due to the synergistic interaction of structurally diverse acetogenins, with the acetogenin rolliniastatin- 1 being the main active ingredient (Ansante et al., 2015; Souza et al., 2017).

Although some synthetic insecticides, including organophosphates, pyrethroids and spinosyns, are highly toxic to D. suzukii (Bruck et al., 2011; Haviland and Beers, 2012; Van Timmeren and Isaacs, 2013; Andreazza et al., 2017a), the use of such products can leave chemical residues on fruits. The concern about these residues increases particularly during the pre-harvest and fruit-ripening periods, which are the periods most preferred for infestation by $D$. suzukii (Bruck et al., 2011; Van Timmeren and Isaacs, 2013; Abraham et al., 2015; Lee et al., 2015; Bernardi et al., 2017). Thus, given the ease of production and rapid degradation and low residual effect (Ribeiro et al., 2016), formulations based on A. mucosa seed-extracts can be an additional tool for use in the management of $D$. suzukii.

The acetogenins are the likely primary active ingredient responsible for arthropod pest mortality in the tested ethanolic extracts (Ribeiro et al., 2013). These molecules are inhibitors of the complex I (NADH:ubiquinone oxidoreductase) in the mitochondrial electron transport system, with inhibition inducing cellular death (Tormo et al., 1999). Because most insecticides used in the control of $D$. suzukii act on acetylcholine receptors or on sodium channels (Casida and Durkin, 2013), the search for products with a different mode of action (e.g., acetogenins) might assist in the management of resistant populations (Audsley and Down, 2015). Currently, populations of D. suzukii resistant to insecticides have not been reported, however, with high polyphagy (Lee et al., 2015; Poyet et al., 2015), a short generation time (Asplen et al., 2015), and rapid dispersion (Haye et al., 2016) associated with the continued use of insecticides, the selection pressure is high for the appearance of resistant populations (Wilson, 2001; Haye et al., 2016).

In addition to the similar lethal toxicity of the formulated $A$. mucosa seed-extract and a spinosyn-based commercial insecticide on $D$. suzukii adults, all tested formulations deterred oviposition by $D$. suzukii females. The level of oviposition deterrence observed in this study (i.e., $45 \%$ ), if alone, would probably not fully contribute to this species management at field, especially at zero-tolerance regions (Van Timmeren and Isaacs, 2013). Nonetheless, its combining effect with the adult mortality could be an important part of an IPM program, where the deterrence of oviposition is beneficial because of the negative effect on the population dynamics in future generations (Kogan, 1998). Furthermore, products that decrease oviposition in D. suzukii reduce the incidence of epidermis rupture by oviposition, which consequently reduces the infestation of pathogens that increase the processes of fruit decay (Mitsui et al., 2006; Walsh et al., 2011; Calabria et al., 2012).

The formulation of $A$. mucosa seed extract through dietary exposure caused low mortality to the pupal parasitoid $T$. anastrephae, which highlights the potential use of this extract in toxic baits. Although the mortality caused by the contact exposure could be considered relatively high, the mortality of the parasitoid was lower than that of D. suzukii, and after ingestion exposure, no sublethal effects on the rate of parasitism by surviving wasps were detected. Thus, the formulated ethanolic seed-extract of $A$. mucosa is a promising tool that is compatible with future biological control programs of $D$. suzukii (Biondi et al., 2012), particularly because $T$. anastrephae were recently found parasitizing pupae of this pest in strawberry and blackberry fields in Brazil (Wollmann et al., 2016; Andreazza et al., 2017b). Furthermore, the compatibility of $A$. mucosa derivatives with isolates of the entomopathogenic fungi Beauveria bassiana (Bals.-Criv.) Vuill and $\mathrm{Me}$ tarhizium anisopliae (Metchnikoff) Sorokin (Ribeiro et al., 2014a), which are also considered promising control agents of $D$. suzukii (Cuthbertson et al., 2014; Gargani et al., 2014), is a positive aspect to include their use in D. suzukii management programs.

In this study, the formulation with the ethanolic seed-extract of $A$. mucosa had promising bioactivity against $D$. suzukii, with toxic effects equivalent to a spinosyn-based commercial insecticide, in addition to a less toxic effect on its pupal parasitoid T. anastrephae. Thus, this formulated extract can be a useful and a promising component for the management of $D$. suzukii, particularly in organic or low residue production systems. This study highlights the importance of future studies to investigate the cropping of $A$. mucosa and efficient derivative extraction and processing.

\section{Acknowledgment}

The authors are grateful to the National Council for the 
Improvement of Higher Education (CAPES) for granting a scholarship to the first author.

\section{References}

Abraham, J., Zhang, A., Angeli, S., Abubeker, S., Michel, C., Feng, Y., Rodriguez-Saona, C., 2015. Behavioral and antennal responses of Drosophila suzukii (Diptera: Drosophilidae) to volatiles from fruit extracts. Environ. Entomol. 44, 356-367.

Alali, F.Q., Liu, X.-X., McLaughlin, J.L., 1999. Annonaceous acetogenins: recent progress. J. Nat. Prod. 62, 504-540

Andreazza, F., Bernardi, D., Marangon, R.B., Scheunemann, T., Botton, M., Nava, D.E., 2016a. Técnica de criação de Drosophila suzukii (Matsumura, 1931) (Diptera: Drosophilidae) em dieta artificial, vol. 240 Boletim de Pesquisa e Desenvolvimento/ Embrapa Clima Temperado (23p.).

Andreazza, F., Haddi, K., Oliveira, E.E., Ferreira, J.A.M., 2016b. Drosophila suzukii (Diptera: Drosophilidae) arrives at Minas Gerais State, a main strawberry production region in Brazil. Fla. Entomol. 99, 796-798.

Andreazza, F., Bernardi, D., Baronio, C.A., Pasinato, J., Nava, D.E., Botton, M., 2017a Toxicities and effects of insecticidal toxic baits to control Drosophila suzukii and Zaprionus indianus (Diptera: Drosophilidae). Pest Manag. Sci. 73, 146-152.

Andreazza, F., Bernardi, D., Nava, D.E., Botton, M., Costa, V.A., 2017b. Inimiga parasitada. Cultivar HF 102, 20-23.

Ansante, T.F., do Prado Ribeiro, L., Bicalho, K.U., Fernandes, J.B., Vieira, P.C., Vendramim, J.D., 2015. Secondary metabolites from Neotropical Annonaceae: screening, bioguided fractionation, and toxicity to Spodoptera frugiperda (JE Smith) (Lepidoptera: Noctuidae). Ind. Crops Prod. 74, 969-976.

Asplen, M.K., Anfora, G., Biondi, A., Choi, D.-S., Chu, D., Daane, K.M., Gibert, P., Gutierrez, A.P., Hoelmer, K.A., Hutchison, W.D., Isaacs, R., Jiang, Z.-L., Kárpáti, Z., Kimura, M.T., Pascual, M., Philips, C.R., Plantamp, C., Ponti, L., Vétek, G., Vogt, H., Walton, V.M., Yu, Y., Zappalà, L., Desneux, N., 2015. Invasion biology of spotted wing Drosophila (Drosophila suzukii): a global perspective and future priorities. J. Pest Sci. 88, 469-494.

Audsley, N., Down, R.E., 2015. G protein coupled receptors as targets for next generation pesticides. Insect Biochem. Mol. Biol. 67, 27-37.

Bernardi, D., Andreazza, F., Botton, M., Baronio, C.A., Nava, D.E., 2017. Susceptibility and interactions of Drosophila suzukii and Zaprionus indianus (Diptera: Drosophilidae) in damaging strawberry. Neotrop. Entomol. 46, 1-7.

Biondi, A., Mommaerts, V., Smagghe, G., Viñuela, E., Zappalà, L., Desneux, N., 2012. The non-target impact of spinosyns on beneficial arthropods. Pest Manag. Sci. 68, 1523-1536.

Blessing, L.D.T., Colom, O.Á., Popich, S., Neske, A., Bardón, A., 2010. Antifeedant and toxic effects of acetogenins from Annona montana on Spodoptera frugiperda. J. Pest Sci. 83, 307-310

Bruck, D.J., Bolda, M., Tanigoshi, L., Klick, J., Kleiber, J., DeFrancesco, J., Gerdeman, B., Spitler, H., 2011. Laboratory and field comparisons of insecticides to reduce infestation of Drosophila suzukii in berry crops. Pest Manag. Sci. 67, 1375-1385.

Calabria, G., Máca, J., Bächli, G., Serra, L., Pascual, M., 2012. First records of the potential pest species Drosophila suzukii (Diptera: Drosophilidae) in Europe. J. Appl. Entomol. 136, 139-147.

Casida, J.E., Durkin, K.A., 2013. Neuroactive insecticides: targets, selectivity, resistance, and secondary effects. Annu. Rev. Entomol. 58, 99-117.

Cini, A., Ioriatti, C., Anfora, G., 2012. A review of the invasion of Drosophila suzukii in Europe and a draft research agenda for integrated pest management. Bull. Insectol. 65, 149-160.

Costa, M.d.S., Paula, S.O.d., Martins, G.F., Zanuncio, J.C., Santana, A.E.G., Serrão, J.E., 2016. Multiple modes of action of the squamocin in the midgut cells of Aedes aegypti larvae. PLoS One 11, e0160928.

Cuthbertson, A.G., Collins, D.A., Blackburn, L.F., Audsley, N., Bell, H.A., 2014. Preliminary screening of potential control products against Drosophila suzukii. Insects 5, 488-498.

Finney, D.J., 1971. Probit Analysis, 3rd ed. Cambridge University Press.

Gargani, E., Tarchi, F., Frosinini, R., Mazza, G., Lazzeri, L., Matteo, R., Simoni, S., 2014. Evaluation of some organic products for spotted wing Drosophila control. In: Proceeding of the IOBC VIII Workshop on Integrated Soft Fruit Production. Trento. pp. 84-85.

Gonçalves, G.L.P., Ribeiro, L.d.P., Gimenes, L., Vieira, P.C., Silva, M.F.d.G.F.d., Forim, M.R., Fernandes, J.B., Vendramim, J.D., 2015. Lethal and sublethal toxicities of Annona sylvatica (Magnoliales: Annonaceae) extracts to Zabrotes subfasciatus (Coleoptera: Chrysomelidae: Bruchinae). Fla. Entomol. 98, 921-928.

Gonçalves, G.L.P., de Cássia Domingues, V., do Prado Ribeiro, L., Fernandes, J.B., das Graças Fernandes, M.d.F., Forim, M.R., Vendramim, J.D., 2017. Compounds from Duguetia lanceolata St. -Hil. (Annonaceae) bioactive against Zabrotes subfasciatus (Boheman)(Coleoptera: Chrysomelidae: Bruchinae). Ind. Crops Prod. 97, 360-367.

Hamby, K.A., Bellamy, D.E., Chiu, J.C., Lee, J.C., Walton, V.M., Wiman, N.G., York, R.M., Biondi, A., 2016. Biotic and abiotic factors impacting development, behavior, phenology, and reproductive biology of Drosophila suzukii. J. Pest Sci. 89, 605-619.

Haviland, D.R., Beers, E.H., 2012. Chemical control programs for Drosophila suzukii that comply with international limitations on pesticide residues for exported sweet cherries. J. Integr. Pest Manag. 3, 1-6.

Haye, T., Girod, P., Cuthbertson, A.G.S., Wang, X.G., Daane, K.M., Hoelmer, K.A., Baroffio, C., Zhang, J.P., Desneux, N., 2016. Current SWD IPM tactics and their practical implementation in fruit crops across different regions around the world. J. Pest Sci. 89, 643-651.

Hinde, J., Demétrio, C.G., 1998. Overdispersion: models and estimation. Comput. Stat
Data Anal. 27, 151-170.

Isman, M.B., Grieneisen, M.L., 2014. Botanical insecticide research: many publications, limited useful data. Trends Plant Sci. 19, 140-145.

Isman, M.B., Seffrin, R., 2014. Natural insecticides from the Annonaceae: a unique example for developing biopesticides. Advances in Plant Biopesticides. Springer (pp 21-33).

Johnson, H.A., Oberlies, N.H., Alali, F.Q., McLaughlin, J., 2000. Thwarting resistance: annonaceous acetogenins as new pesticidal and antitumor agents. In: Cutler, S.J., Cutler, H.G. (Eds.), Biological Active Natural Products: Pharmaceuticals. CRC Press LLC, Boca Raton, FL (pp. 173-183).

Kogan, M., 1998. Integrated pest management: historical perspectives and contemporary developments. Annu. Rev. Entomol. 43, 243-270.

Lee, J.C., Dreves, A.J., Cave, A.M., Kawai, S., Isaacs, R., Miller, J.C., Van Timmeren, S., Bruck, D.J., 2015. Infestation of wild and ornamental noncrop fruits by Drosophila suzukii (Diptera: Drosophilidae). Ann. Entomol. Soc. Am. 108, 117-129.

Mitsui, H., Takahashi, K.H., Kimura, M.T., 2006. Spatial distributions and clutch sizes of Drosophila species ovipositing on cherry fruits of different stages. Popul. Ecol. 48, 233-237.

Nelder, J.A., Wedderburn, R.W.M., 1972. Generalized linear models. J. R. Stat. Soc. Ser. A (Gen.) 135, 370-384.

Poyet, M., Le Roux, V., Gibert, P., Meirland, A., Prévost, G., Eslin, P., Chabrerie, O., 2015. The wide potential trophic niche of the asiatic fruit fly Drosophila suzukii: the key of its invasion success in temperate Europe? PLoS One 10, e0142785.

R, D.C.T, 2012. R: A Language and Environment for Statistical Computing. R Foundation for Statistical Computing, Vienna (Online:). https://http://www.r-project.org/.

Ribeiro, L.P., Vendramim, J.D., Bicalho, K.U., Andrade, M.d.S., Fernandes, J.B., Moral, R.d.A., Demétrio, C.G.B., 2013. Annona mucosa Jacq. (Annonaceae): a promising source of bioactive compounds against Sitophilus zeamais Mots. (Coleoptera: Curculionidae). J. Stored Prod. Res. 55, 6-14.

Ribeiro, L.P., Mota, L.H.C., D’Alessandro, C.P., Vendramim, J.D., Delalibera Júnior, I., 2014a. In vitro compatibility of an acetogenin-based bioinsecticide with three species of entomopathogenic fungi. Fla. Entomol. 97, 1395-1403.

Ribeiro, L.P., Zanardi, O.Z., Vendramim, J.D., Yamamoto, P.T., 2014b. Comparative toxicity of an acetogenin-based extract and commercial pesticides against citrus red mite. Exp. Appl. Acarol. 64, 87-98.

Ribeiro, L.P., Akhtar, Y., Vendramim, J.D., Isman, M.B., 2014c. Comparative bioactivity of selected seed extracts from Brazilian Annona species and an acetogenin-based commercial bioinsecticide against Trichoplusia ni and Myzus persicae. Crop Prot. 62, $100-106$.

Ribeiro, L.P., Vendramim, J.D., Andrade, M.S., Bicalho, K.U., Silva, M.F.G.F., Vieira, P.C., Fernandes, J.B., 2014d. Tropical plant extracts as sources of grain-protectant compounds against Sitophilus zeamais Motschulsky (Coleoptera: Curculionidae). Neotrop. Entomol. 43, 470-482.

Ribeiro, L.P., Santos, M.S., Gonçalves, G.L.P., Vendramim, J.D., 2015. Toxicity of an acetogenin-based bioinsecticide against Diaphorina citri (Hemiptera: Liviidae) and its parasitoid Tamarixia radiata (Hymenoptera: Eulophidae). Fla. Entomol. 98, 835-842.

Ribeiro, L.P., Vendramim, J.D., Gonçalves, G.P., Ansante, T.F., Gloria, E.M., Lopes, J.C. Mello-Silva, R., Fernandes, J.B., 2016. Searching for promising sources of grain protectors in extracts from Neotropical Annonaceae. Bol. Latinoam. Caribe Plantas Med. Aromát. 15, 215-232.

Roubos, C.R., Rodriguez-Saona, C., Holdcraft, R., Mason, K.S., Isaacs, R., 2014. Relative toxicity and residual activity of insecticides used in blueberry pest management: mortality of natural enemies. J. Econ. Entomol. 107, 277-285.

SAS Institute, 2011. Statistical Analysis System: Getting Started with the SAS Learning, 9.2 ed. SAS Institute, Carry, NC.

Santos, R.S.S., 2014. Ocorrência de Drosophila suzukii (Matsumura, 1931) (Diptera: Drosophilidae) atacando frutos de morango no Brasil. Comunicado Técnico, Embrapa, Bento Gonçalves (p. 4).

Schlesener, D.C.H., Nunes, A.M., Cordeiro, J., Gottschalk, M.S., Garcia, F.R.M., 2014. Mosca-da-cereja (Drosophila suzukii): uma nova ameaça para a fruticultura brasileira. Cultivar HF 12, 6-8.

Souza, C.M., Baldin, E.L.L., Ribeiro, L.P., Silva, I.F., Morando, R., Bicalho, K.U., Vendramim, J.D., Fernandes, J.B., 2017. Lethal and growth inhibitory activities of neotropical Annonaceae-derived extracts, commercial formulation, and an isolated acetogenin against Helicoverpa armigera. J. Pest Sci. 90, 701-709.

Tochen, S., Dalton, D. T., Wiman, N., Hamm, C., Shearer, P.W., Walton, V.M., 2014. Temperature-related development and population parameters for Drosophila suzukii (Diptera: Drosophilidae) on cherry and blueberry. Environ. Entomol. 43, 501-510.

Tormo, J., Gallardo, T., González, M., Bermejo, A., Cabedo, N., Andreu, I., Estornell, E., 1999. Annonaceous acetogenins as inhibitors of mitochondrial complex I. Curr. Top. Phytochem. 2, 69-90.

Van Timmeren, S., Isaacs, R., 2013. Control of spotted wing drosophila, Drosophila suzukii, by specific insecticides and by conventional and organic crop protection programs. Crop Prot. 54, 126-133.

Walsh, D.B., Bolda, M.P., Goodhue, R.E., Dreves, A.J., Lee, J., Bruck, D.J., Walton, V.M., O'Neal, S.D., Zalom, F.G., 2011. Drosophila suzukii (Diptera: Drosophilidae): invasive pest of ripening soft fruit expanding its geographic range and damage potential. J. Integr. Pest Manag. 2, 1-7.

Wilson, T.G., 2001. Resistance of Drosophila to toxins. Annu. Rev. Entomol. 46, 545-571. Wollmann, J., Schlesener, D.C.H., Ferreira, M.S., Garcia, M.S., Costa, V A., Garcia, F. R.M. 2016. Parasitoids of Drosophilidae with potential for parasitism on Drosophila suzukii in Brazil. Note Sci. Drosoph. Inf. Serv. 99, 38-42.

Zanardi, O.Z., Ribeiro, L.d.P., Ansante, T.F., Santos, M.S., Bordini, G.P., Yamamoto, P.T., Vendramim, J.D., 2015. Bioactivity of a matrine-based biopesticide against four pest species of agricultural importance. Crop Prot. 67, 160-167. 